\title{
Åpne barnehager som rekrutteringsarena for ordinær barnehage
}

\author{
Anne Sigrid Haugset*, \\ Trøndelag Forskning og Utvikling, Steinkjer, Norge
}

\begin{abstract}
Sammendrag
Åpne barnehager i Norge møter en forventning fra myndighetene om å være en rekrutteringsarena for ordinær barnehage (Regjeringen, 2012). Forventningen er en naturlig forlengelse av barnehagen som første trinn i utdanningsløpet, men kan også oppleves problematisk fordi barnehagen er frivillig og deler av norsk barneomsorgspolitikk også betoner familiens rett til å velge den bort. I denne undersøkelsen giør ledere av kommunalt og privat eide åpne barnehager vurderinger av barnehagen som rekrutteringsarena. De som leder kommunale barnehager med mange minoritetsspråklige brukere tror mest på rekrutteringseffekter i sin åpne barnehage. De kommunale åpne barnehagene har også mer aktivitet rettet mot rekruttering til ordinær barnehage enn barnehager med andre eiere. Datamaterialet viser at dilemmaet rundt rekruttering oppleves av barnehagelederne som «hvem av brukerne skal rekrutteres, og hvem skal støttes i valget sitt»? I dette spørsmålet brukes minoritetsspråklig bakgrunn som et av kriteriene. Det kan synes som det i hovedsak er minoritetsspråklige familier som blir aktivt oppmuntret til å søke barnehageplass.
\end{abstract}

Nøkkelord: Førskoletilbud; barneomsorg; minoritetsspråklige

\begin{abstract}
Open day care institutions in Norway are expected to contribute to recruiting children to kindergartens (Regjeringen, 2012). This expectation can be argued to follow naturally from the kindergarten's newly acquired position as the first step of the educational ladder. It may, however, be perceived at odds with kindergarten as a voluntary service and Norwegian early child care policy that supports both family- and kindergarten care. In this survey the leaders of open day care institutions evaluates to which degree their institution has a recruiting function. Leaders in publicly owned open day care institutions and institutions with a high rate of minority language users are the firmest believers in this recruiting function. Publicly owned open day care institutions also offer more activities aimed at recruiting to kindergarten than those owned by the church. Our data shows that the leaders of open day care perceives the task of recruiting as a dilemma: Which families should be supported in their choice, and which should be "gently pushed» towards kindergarten? In this situation the leaders tend to use the family's language background as a guideline - it seems as mainly the minority language users are actively encouraged to use the kindergarten.
\end{abstract}

\section{Keywords: Pre-school education; child care; language minorities}

Received: June 2015; Accepted: January 2016; Published: April 2016

^Korrespondanse: Anne Sigrid Haugset, Trøndelag Forskning og Utvikling AS, Postboks 2401, N-7729 Steinkjer, E-post: anne.s.haugset@tfou.no 


\section{Innledning}

Åpne barnehager er barnehager med uforpliktende oppmøte, uten tildeling av fast plass og der foresatte deltar sammen med barnet. I stortingsmeldingen Framtidens barnehage (Regjeringen, 2012) beskrives åpen barnehage som et lavterskeltilbud og en tilgjengelig arena for foreldre og barn som ikke benytter seg av det ordinære barnehagetilbudet. I tillegg pekes det på at «Åpne barnehager kan vare en viktig arena for rekruttering av barn til ordinar barnehage» (side 37). Formålet med denne artikkelen er å beskrive hva som kjennetegner åpne barnehager der barnehagens ledelse ${ }^{1}$ mener barnehagen bidrar til å rekruttere barn til ordinær barnehageplass ${ }^{2}$. Artikkelen kaster også lys over vurderinger og avveininger som giøres når det gjelder rekruttering til ordinær barnehage, gjennom barnehagelederne $i$ åpen barnehage som informanter.

Det er generelt forsket lite på norske åpne barnehager (Haugset \& Sivertsen, 2014), ut over kartlegginger (Tingstad \& Kvamstad, 1998), evalueringer av konkrete barnehager eller grupper av barnehager (Mortensen \& Fosse, 2006; Thyrhaug, 2009) og beskrivende, kvalitative case-undersøkelser (Emhjellen, 2008; Erstad, 2012; Filipovic-Kittelsen, 2008, Hatlem, 2008; Mellin-Olsen, 2014). Jeg har ikke funnet studier som eksplisitt undersøker åpne barnehagers funksjon som rekrutteringsarena for ordinær barnehage. Artikkelen gir både en oversikt over fellestrekk ved de åpne barnehagene som synes å rekruttere til ordinær barnehage, og et innblikk i vurderinger som giøres i barnehagen rundt det å forsøke å rekruttere til ordinær barnehage.

\section{Åpen barnehage mellom utdanningspolitikk og et tvetydig barneomsorgsregime}

Med rekruttering til ordinær barnehage menes at den åpne barnehagen bidrar til at barn i familier som ellers ikke ville søkt om og benyttet barnehageplass før skolestart, kommer i ordinær barnehage. Åpne barnehagers funksjon som rekrutteringsarena til ordinær barnehage må forstås i lys av både utdanningspolitiske strømninger og det rådende omsorgsregimet velferdsstaten tilbyr småbarnsfamiliene. Med økende dekningsgrad har den politiske interessen for barnehagen som utdanningspolitisk prosjekt tiltatt de siste årene. Det har skjedd betydelige endringer i barnehagens innhold og formål, blant annet som følge av at barnehagen ble overført fra Barneog familiedepartementet til Kunnskapsdepartementet og definert som pedagogisk virksomhet og en del av utdanningssystemet (Thoresen, 2009, s. 128). Samtidig som barnehagen ble forstått som et første viktig, men frivillig, trinn på utdanningsstigen, økte fokuset på rekruttering av barn og det å inkludere flest mulig. Det er gjort grep for å giøre barnehageplass mer tilgjengelig for flere, blant annet i 2006 gjennom makspriser som har gitt billigere barnehageplasser for familiene, og lovfestet rett til barnehageplass fra 2009. Barn i familier med høy sosioøkonomisk status har fortsatt i

\footnotetext{
${ }^{1}$ Henvendelsen gikk til styrer, subsidiært pedagogisk leder, av åpne barnehager. 53 prosent av de som har svart oppgir at de er styrer, 31 prosent er pedagogisk leder og 16 prosent har andre sentrale roller (styreleder, eier, pedagog, etc.). I det følgende benyttes «barnehagens ledelse» eller «barnehagelederne» om respondentene i undersøkelsen.

${ }^{2}$ I denne artikkelen refererer «ordinær barnehage» til alle barnehager som tildeler barnet fast plass. Begrepet inkluderer derfor både private og kommunale barnehager og familiebarnehager.
} 


\section{A. S. Haugset}

noe større grad barnehageplass enn barn i mindre ressurssterke familier (Regjeringen, 2012), og blant barn som ikke går i barnehage, er familier med innvandrer- og minoritetsspråklig bakgrunn overrepresentert (Utdanningsdirektoratet, 2015, s. 9). Dette er problematisk både fra et utjevningsperspektiv og et pedagogisk perspektiv (Ellingsæter \& Gulbransen, 2003). Forskning tyder på at mange blant de fem prosent av barna mellom tre og fem år som ikke går i barnehagen i dag, ville hatt spesielt stort utbytte av å benytte tilbudet. Det synes å være spesielt viktig for barn fra minoritetsspråklige familier å gå i barnehage (Drange \& Telle, 2011), og et universelt barnehagetilbud kommer også barn fra familier med lav utdanning og inntekt mest til gode (Havnes \& Mogstad, 2009; Mogstad \& Rege, 2009). Med utgangspunkt i dette er det meningsfullt å diskutere åpne barnehagers potensial for å rekruttere barn til ordinær barnehageplass, som et middel for utjevning av sosiale forskjeller.

Rekruttering til ordinær barnehage må også forstås på bakgrunn av at barnehagen er et frivillig tilbud helt fram til skolestart. Norge kan sies å ha et dualistisk eller tvetydig barneomsorgsregime, som understøtter og oppmuntrer både omsorg i hjemmet og offentlig omsorgstilbud (Ellingsæter, 2012; Ellingsæter \& Widerberg, 2012). Rause permisjonsordninger fra lønnet arbeid er en anerkjennelse av verdien til foreldreomsorgen i barnets første leveår, mens tilnærmet full barnehagedekning med rett til plass senest fra 2 års alder oppmuntrer til omsorg utenfor hjemmet slik at begge foreldrene kan være yrkesaktive. Omfattende offentlig barneomsorg begrunnes først og fremst på samfunns- eller makronivået: Frigjøring av arbeidskraft, investering i framtidas arbeidskraft og sosial utjevning gjennom like muligheter for alle $i$ kunnskapssamfunnet uavhengig av familiens utgangspunkt (Leira, 2012). Leira peker på at «dermed blir kvalitetskrav og kostnader med småbarnsomsorgen for viktige og for store til å bli overlatt til foreldrene aleine» (Leira, 2012, s. 94). Samtidig gis kontantstøtte for ettåringer, noe som stimulerer private barneomsorgsordninger for barn mellom ett og to år og begrunnes ut fra familiens rett og økonomiske mulighet til å velge (Ellingsæter, 2012). Ellingsæter beskriver kontantstøtten som en «motvekt» til ekspanderende offentlig barneomsorg.

Valgfriheten i bruk av barnehagen til tross, familier som velger bort barnehagen kan oppleve at standpunktet deres utfordres. Foreldre som hadde valgt hjemmeomsorg fram til skolestart, framstår i Seebergs (2010) forskning som reflekterte, ressurssterke og bevisste på at de hadde brukt retten sin til å velge bort barnehagen. Foreldrene var bevisste på at dette var et valg de ville bli nødt til å forsvare i møte med sterke samfunnsnormer om at barnehagen er det beste stedet å være for barna. Seeberg fant tre hovedkategorier av slike familier: Samisk foreldre som er opptatt av å videreføre samisk kultur og livsform, foreldre med annen språklig bakgrunn enn den norske som ønsker å forankre barnet godt i eget morsmål før møtet med «storsamfunnets» språk og verdikonservative foreldre som mener familien og hjemmet er bedre egnet for omsorg for små barn enn barnehagen. Foreldrene la vekt på barnets behov for fred og ro, for å være sammen med foreldrene i hjemmet og for avskjerming fra en stressende og krevende hverdag. De betonte også gleden de som foreldre har av å bruke tid med barnet. Seebergs undersøkelse viser at denne gruppen foreldre setter stor pris på tilbudet om åpen barnehage. Den åpne barnehagen ivaretar barnas behov for sosial 
kontakt med andre barn, den gir et pedagogisk kvalifisert tilbud noen timer/dager hver uke som supplerer hjemmeomsorgen, og den gir foreldrene en sosial arena (Seeberg, 2010). Sett i dette perspektivet er åpne barnehager som rekrutteringsarena for ordinær barnehage ikke helt uproblematisk, fordi det kan oppfattes som et forsøk på å overprøve foreldrenes rett til å velge det de mener er best for sine barn.

Rekruttering av barn til ordinær barnehage gjennom deltakelse $\mathrm{i}$ åpen barnehage synes med dette å være en slags balanseøvelse mellom det å sikre alle grupper en best mulig start i samfunnets store utdannings- og utjevningsprosjekt, og hensynet til familienes rett til selv å velge omsorgsform for egne barn ut fra egne verdier, ønsker og kriterier.

\section{Åpne barnehager og brukerne deres}

I åpen barnehage er det alltid en forelder eller annen voksen omsorgsperson til stede sammen med barnet. Tilbudet er uforpliktende, og deltakerne kan komme og gå som de vil innenfor åpningstiden, som ofte er noe kortere enn en vanlig barnehagedag (Haugset \& Sivertsen, 2014, s. 31). Funksjoner som trekkes fram er sosialt nettverk i nærmiljøet, mulighet for tidlig innsats for barn med særskilte behov og språkstimulering $\mathrm{i}$ norsk for elever som trenger dette og som ikke går $\mathrm{i}$ ordinær barnehage (Regjeringen, 2012, s. 26). I dag finnes det cirka 200 åpne barnehager fordelt på 20 prosent av de norske kommunene, og nesten halvparten av barnehagene ligger $\mathrm{i}$ byer eller større tettsteder ${ }^{3}$ (Håkonsen, Løyland \& Aastvedt, 2014). Halvparten av åpne barnehager eies og drives av kommunen. Blant de private tilbyderne av åpne barnehager dominerer menigheter eller trossamfunn, som eier cirka 30 prosent av de åpne barnehagene (Haugset \& Sivertsen, 2014, s. 28). Det har vist seg krevende å skaffe oversikt over hvor mange barn og familier som faktisk benytter seg av åpne barnehager, fordi registrerings- og tellerutinene ikke er enhetlige. Det ble gjort et anslag på en godkjent total kapasitet på cirka 6000 barn, men tallet er svært usikkert (Haugset, Gotvassli, Ljunggren \& Stene, 2014, s. 42).

De åpne barnehagene var opprinnelig et alternativ til fast barnehageplass, som var et knapt gode ikke alle fikk tilgang til (Hatlem \& Frank, 2009). I takt med barnehageutbyggingen har brukergruppen endret seg, fra barn som nærmet seg skolestart til en overvekt av ett- og toåringer. Mange foreldre i permisjon og foreldre som venter på sin lovfestede barnehageplass bruker åpen barnehage, mens innslaget av de eldste barnehagebarna er lite (Haugset et al., 2014). Den samme aldersforskyvingen ser en i öppen förskola i Sverige (Skolverket, 2005), som ifølge Hatlem og Frank (2009) er det eneste andre landet som har åpne barnehager som kan sammenlignes med de norske. Mange av de åpne barnehagene, spesielt de kommunale, har et betydelig innslag av brukere som er fler- eller minoritetsspråklige (Haugset et al., 2014). Å ha en annen kulturell og språklig bakgrunn enn den norske kan påvirke foreldres oppfatning av hva som er en god omsorgsløsning for barn under skolealder (se f. eks Nadim, 2012).

\footnotetext{
${ }^{3}$ Ifølge Håkonsen et al. (2014, s. 82) ligger 45 prosent av de åpne barnehagene i kommunene Bergen, Bærum, Drammen, Fredrikstad, Kristiansand, Oslo, Sandnes, Stavanger, Trondheim og Tromsø.
} 


\section{A. S. Haugset}

\section{Rekruttering til ordinær barnehage}

Det å bidra til rekruttering til ordinær barnehage betinges selvsagt av at den åpne barnehagen har brukere som kan rekrutteres. Et fåtall åpne barnehager oppgir å ha mange slike brukere, mens to av tre svarer at de har innslag av familier som ikke planlegger fast barnehageplass (Haugset et al., 2014, s. 46).

Som påpekt ovenfor er åpne barnehager som rekrutteringsarena for ordinær barnehage en balansegang mellom flere hensyn, både på samfunns- og individnivå. Det er derfor sannsynligvis variasjon i hvor opptatt ledelsen i de åpne barnehagene er av rekruttering og bistand til å komme over i ordinær barnehageplass. Sannsynligvis påvirkes dette av lederens egen oppfatning av åpen barnehages oppgaver og rolle overfor ulike brukergrupper, noe som belyses i det tekstlige datamaterialet som presenteres under. Samtidig kan også forhold ved selve barnehagen, som organisering og omfang av tilbudet, ha sammenheng med rekrutteringsfokuset. Private åpne barnehager har, i likhet med andre private barnehager, frihet til å fastsette egne vedtekter og opptakskriterier innenfor rammene av lover og forskrifter (barnehageloven, paragraf 7). Barnehagens eierforhold kan gjennom dette ha betydning for fokuset på rekruttering til ordinær barnehage.

Mekanismene for en eventuell rekrutterende funksjon er flere. For familier som er ukjente med eller usikre på barnehagen som institusjon, vil møtet med barnehagehverdagen sammen med barnet i seg selv styrke beslutningsgrunnlaget deres. Åpen barnehage har mange aktiviteter og rutiner felles med ordinære barnehager: Samlingsstund, sangstund, felles måltid, formingsaktiviteter og til en viss grad uteaktiviteter og turer. I tillegg til dette kommer eventuelt mer direkte og aktivt rekrutteringsarbeid.

\section{Forskningsspørsmål}

I det påfølgende avsnittet benyttes data fra en spørreundersøkelse til ledere av åpne barnehager for å søke svar på:

- Hva kjennetegner åpne barnehager som synes å rekruttere barn til ordinær barnehage?

- Hvor utbredt er ulike former for rekrutteringsaktivitet?

- Hvilke vurderinger gjøres i åpne barnehager når det gjelder rekruttering til ordinær barnehage?

\section{Datagrunnlag og metoder}

Å undersøke om åpne barnehager faktisk har en rekrutterende effekt er vanskelig, ikke minst fordi brukere av åpen barnehage ikke registreres på samme måte som barn med barnehageplass. Det er dermed vanskelig å koble sammen registerdata om bruk av åpen barnehage og videre veg gjennom utdanningssystemet, inkludert ordinær barnehage. Manglende registrering av brukerne gjør også spørreundersøkelser til et representativt utvalg av familier som benytter åpen barnehage, vanskelig. En må derfor finne andre, mer indirekte strategier for å kaste lys over spørsmålet. 


\section{Datamateriale}

Datamaterialet denne artikkelen bygger på, er innhentet $\mathrm{i}$ forbindelse med en utredning av åpne barnehager i 2013-2014 (Haugset et al., 2014). Det ble gjennomført en e-postbasert spørreundersøkelse blant ledere av totalt 222 åpne barnehager ${ }^{4}$. Spørreundersøkelsen resulterte i svar fra 138 personer på de spørsmålene som er benyttet i denne analysen.

Undersøkelsen inneholdt spørsmål om barnehagens funksjon som rekruttering til ordinær barnehage, om brukerne og bruksmønsteret deres, om aktiviteter rettet mot overgang til ordinær barnehage og om åpningstider, eierform og organisering. Datamaterialet inneholder også mange og omfattende tekstkommentarer, knyttet både til åpen barnehage generelt og til konkrete spørsmål i spørreskjemaet.

I undersøkelsen har barnehagelederne gjort erfaringsbaserte vurderinger av i hvor stor grad han eller hun mener den åpne barnehagen bidrar til at barn rekrutteres til ordinær barnehage. Det er åpenbare metodiske svakheter ved dette med hensyn til å beskrive årsakssammenhenger og faktisk rekrutteringseffekt av åpne barnehager: Lederen kan gjøre feilvurderinger eller mangle kunnskap om foreldrenes intensjoner. En får heller ikke kontrollert for andre forhold som kanskje ville påvirket barnehagestart uavhengig av deltakelse $\mathrm{i}$ åpen barnehage. Det er likevel rimelig å anta at styrer eller pedagogisk leder, som vanligvis er den eneste eller en av to ansatte $\mathrm{i}$ åpne barnehager (Haugset \& Sivertsen, 2014, s. 57), kjenner brukerfamiliene godt. Ambisjonen har først og fremst vært å beskrive variasjonen mellom ulike barnehager med tanke på rekruttering og rekrutteringsarbeid, og dessuten beskrive ulike vurderinger som ledelsen og ansatte gjør rundt den åpne barnehagen som rekruttering til ordinær barnehage. Datamaterialet vurderes slik det foreligger til å ha god reliabilitet og validitet for dette formålet.

\section{Variabler}

Barnehageledernes vurdering av i hvor stor grad barnehagen har en rekrutteringsfunksjon er målt ved å stille dem spørsmålet:

Hvis du tar utgangspunkt $i$ dagens brukere av din åpne barnehage: I hvor stor grad vil du si at barnehagen fungerer som et tilbud som bidrar til at flere barn søker om barnehageplass $i$ ordincer barnehage?

Svarfordelingen er vist i figur 1 .

Barnehagens leder er bedt om å anslå hvor stor prosentandel av brukerne som har annet morsmål enn nordiske språk eller engelsk ${ }^{5}$ (Andel minoritetsspraiklige). På samme måte er det også bedt om et anslag på Andel faste brukere av barnehagen, definert som brukere som benytter tilbudet fast en eller flere ganger i uka over en periode lenger enn to måneder. Tilbudets omfang er representert ved Antall dager

\footnotetext{
${ }^{4}$ Det mangler fullstendige register over all virksomhet som kaller seg åpen barnehage. Se Haugset og Sivertsen, 2014, s. 20-21, for en beskrivelse av hvordan man kom fram til de 222 som ble kontaktet.

${ }^{5}$ Definisjonen av minoritetsspråklig er gjort i tråd med Utdanningsdirektoratets retningslinjer for tilskudd til barn med minoritetsspråklig bakgrunn og rapporteringsrutiner i BASIL.
} 


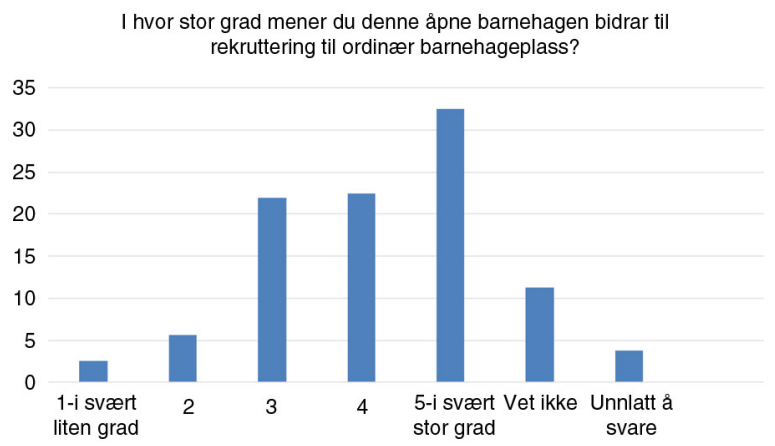

Figur 1. Svarfordeling på barnehageleders vurdering av den åpne barnehagens rekrutterende funksjon. I analysene av samvariasjoner er de 18 som har svart «vet ikke» satt som manglende svar.

i uka og Antall timer per dag tilbudet er åpent. En beskrivelse av disse kontinuerlige variablene er gjort i tabell 1.

De øvrige variablene er dikotomier: Variabelen Betydelig rekrutteringsgrunnlag angir barnehager der leder svarer at de har en del eller mange brukere som benytter åpen barnehage som eneste planlagte barnehagetilbud fram mot skolestart (16,2 prosent av barnehagene). Eierskap er menighetsbarnehager (29,9 prosent av barnehagene) og kommunale barnehager (49,4 prosent), samt en samlekategori andre typer eiere (20,7 prosent) som representerer et stort mangfold av ikke-kommunale eiere. Egne dikotome variabler angir barnehager som er en del av en ordinar barnehage (34,0 prosent), er en del av familiesenter (11,0 prosent) og/eller har helt eller delvis alderstilpasset tilbud (49,7 prosent). Hvilken vekt den åpne barnehagen legger på overgang til ordinære barnehager er målt gjennom spørsmål om hvorvidt man i løpet av de tre siste måneder ${ }^{6}$ har Informert om hverdag/rutiner $i$ ordincer barnehage $(83,3$ prosent), gitt Hjelp til utfylling av barnehagesøknad (41,7 prosent), Gitt råd om hvilken barnehage foreldrene bør søke plass $i$ (53,5 prosent), Framskaffet oversikt over ledige barnehageplasser (27,8 prosent), Arrangert besøk til ordincer barnehage (18,4 prosent) og Informert om ulike barnehager $i$ kommunen (80,1 prosent).

Materialet er analysert med tanke på samvariasjoner mellom variablene ${ }^{7}$.

\footnotetext{
${ }^{6}$ Undersøkelsen er gjennomført ultimo mars 2014.

${ }^{7}$ Det er benyttet bivariate analysemetoder i henhold til variablenes målenivå (krysstabulering, variansanalyse/ANOVA og korrelasjonsanalyser), med tilhørende mål for styrken på sammenhengen (Cramer's V, Pearson's r og Eta kvadrert, Ringdal, 2007). Disse analysene er supplert med en multivariat analyse i form av en OLS-regresjon. Jeg gjør ikke slutninger om årsakssammenhenger, men undersøker om samvariasjonen for hver enkelt uavhengig variabel fortsatt er signifikant når det kontrolleres for de øvrige variablene. Siden dette er en undersøkelse der hele populasjonen av åpne barnehager er invitert og det ikke er trukket noe utvalg, viser signifikanstester til stokastisk modellteori og må tolkes som sannsynligheten for at sammenhenger jeg finner ikke skyldes tilfeldig variasjon $\mathrm{f}$. eks i hvordan spørsmålene ble tolket og besvart av respondentene (Jacobsen, 2013).
} 
Tabell 1. Oversikt over svarfordelingen på variablene som er benyttet i analysen.

\begin{tabular}{lll}
\hline Variabel & N & Svarfordeling/gjennomsnitt \\
\hline Andel minoritetsspråklige & 137 & I snitt 29,2\% av brukerne (std.avvik 25,1\%) \\
Andel faste brukere & 143 & I snitt 60,8\% av brukerne (std. avvik 22,7\%) \\
Antall dager i uka barnehagen har åpent & 153 & I snitt 2,6 dager (std. avvik 1,2 dager) \\
Antall timer tilbudet gis (per dag åpent) & 113 & I snitt 4,8 timer (std. avvik 1,3 timer) \\
\hline
\end{tabular}

\section{Resultater og funn}

I dette avsnittet presenteres og drøftes funn som er gjort i analysene av datamaterialet.

\section{Kommunale barnehager med mange minoritetsspråklige rekrutterer mest}

Det er systematisk samvariasjon mellom den rekrutterende effekten lederne mener at den åpne barnehagen har, og barnehagens eierskap, åpningstid og andel minoritetsspråklige brukere:

- I barnehager med høy andel minoritetsspråklige brukere rapporterer leder om større grad av rekruttering til ordinær barnehage. Denne sammenhengen er relativt sterk (Pearsons $\mathrm{r}=.371, \mathrm{p}<.01$ ).

- Kommunale barnehager rapporterer om større grad av rekruttering til ordinær barnehage enn hva menighetsbarnehagene gjør (eta kvadrert $=.145, \mathrm{p}<.01$ ).

- Barnehager som har åpent fire eller fem dager i uka har noe høyere skår på leders vurderte rekrutteringseffekt enn barnehager som har åpent en til tre dager i uka (Pearsons $\mathrm{r}=.200, \mathrm{p}<.05$ ).

Verken åpningstid i antall timer per dag, andelen faste brukere, om barnehagen er en del av en ordinær barnehage eller lokalisert i et familiesenter, betydelig andel brukere som ikke planlegger ordinær barnehage eller aldersdeling av tilbudet synes å være systematisk relatert til barnehagens rekrutteringsfunksjon.

Andelen av minoritetsspråklige brukere er størst i kommunale åpne barnehager og lavest i menighetsbarnehagene (Haugset \& Sivertsen, 2014, s. 71). For å undersøke samvariasjonen hver enkelt av dem har med barnehagens rekrutteringsfunksjon, kontrollert for hverandre, er det gjennomført en regresjonsanalyse (tabell 2). I modell 3 er også antall dager barnehagen har åpent per uke inkludert, for å se om dette fortsatt samvarierer med rekrutteringsfunksjonen etter kontroll for eierskap og andel minoritetsspråklige brukere.

Tabell 3 viser at forskjellen mellom ledere i menighetsbarnehager og kommunale barnehager reduseres noe, men holder seg signifikant også etter kontroll for at kommunale åpne barnehager har flere brukere med minoritetsspråklig bakgrunn. Menighetsbarnehager skårer 0,8 skalatrinn lavere på leders vurdering av barnehagens rekrutteringsfunksjon, mens det er liten forskjell mellom kommunale barnehager og barnehager med annet eierskap. Når andelen minoritetsspråklige brukere øker med 


\section{A. S. Haugset}

Tabell 2. OLS-regresjon av ledernes vurdering av i hvor stor grad barnehagen bidrar til å rekruttere til ordinær barnehage, på barnehagens eierskap, andel minoritetsspråklige brukere og åpningstid.

\begin{tabular}{lccc}
$\begin{array}{l}\text { OLS-regresjon av grad av rekrutteringsfunksjon på } \\
\text { følgende variabler: }\end{array}$ & Modell 1 & Modell2 & Modell 3 \\
\hline $\begin{array}{l}\text { Eierskap (kommunale barnehager er referansekategori) } \\
\quad \text { Eid av menighet/trossamfunn }\end{array}$ & $-0,98^{\star \star}(1,22)$ & $-0,80^{\star \star}(0,213)$ & $-0,78^{\star \star}(0,21)$ \\
$\quad$ Andre typer eierskap & $-0,14(0,222)$ & $-0,078(0,214)$ & $-0,066(0,210)$ \\
Andel minoritetsspråklige brukere (leders anslag) & & $0,011^{\star \star}(0,003)$ & $0,010^{\star \star}(0,03)$ \\
Antall dager åpent per uke & & $0,163^{\star}(0,072)$ \\
Konstant & $4,21^{\star \star}(1,22)$ & $3,81^{\star \star}(0,17)$ & $3,39^{\star \star}(0,25)$ \\
R-kvadrert & 0,16 & 0,23 & 0,26 \\
\hline
\end{tabular}

${ }^{\star}=$ signifikant på $\mathrm{p}<.05$-nivå. ${ }^{\star \star}=$ signifikant på $\mathrm{p}<.01$-nivå.

10 prosent, øker rekrutteringsfunksjonen med 0,10 skalatrinn. Flere dager åpent per uke henger sammen med litt større tro på rekruttering: Ledere i barnehager som har åpent fire dager i uka vurderer i gjennomsnitt rekrutteringsfunksjonen til å være 0,33 skalatrinn høyere enn der barnehagen har åpent to dager i uka.

\section{Mer fokus på rekruttering i kommunale barnehager}

Alle rekrutteringsaktivitetene, som er presentert i tabell 3, har lavere forekomst i menighetsbarnehagene enn i de øvrige barnehagene. Forskjellene er imidlertid bare signifikant for informasjon om hverdag og rutiner $i$ ordincer barnehage, hjelp til utfylling av søknad og arrangere besøk til ordinar barnehage. Det å informere om hverdag og rutiner i ordinær barnehage, informere om ulike barnehager i kommunen og hjelpe til med å fylle ut søknadsskjema er dessuten mer vanlig i barnehager som vurderer seg selv til å ha en stor rekrutteringsfunksjon. Forskjellen er størst når det gjelder å gi brukerne informasjon om rutiner og hverdag $\mathrm{i}$ ordinære barnehager (Cramer's $\mathrm{V}=.377, \mathrm{p}<.01$ ).

\section{Barnehageledernes tanker om rekruttering til ordinær barnehage}

Spørreundersøkelsen ga rikelig rom for å skrive kommentarer til spørsmålene (åpne tekstfelt), og en del respondenter har kommentert den åpne barnehagens rekrutterende effekt. Det er naturligvis vanskelig for dem som barnehageledere å vite om rekrutteringseffekten er til stede, men flere hevder at den åpne barnehagen uansett gjør overgangen til ordinær barnehageplass lettere:

Mange av brukerne $i$ åpen barnehage søker på plass $i$ ordinar barnehage, uten at vi kan si at det er åpen barnehage som styrer det. Men det er trygt for barna når de kommer til vår barnehage og møter igjen de to som er $i$ åpen (kommunal åpen barnehage).

De som beskriver hvordan rekrutteringsarbeidet i barnehagen foregår, forteller at de «målretter» rekrutteringsarbeidet mot de som vet minst og som trenger fast plass mest (leder for privat åpen barnehage). Ofte trekkes barn og familier med annen språkbakgrunn enn norsk fram som en gruppe som «trenger det mest»: 
Tabell 3. Gjennomføring av rekrutteringsaktiviteter siste tre måneder. Andelen barnehager som har gjennomført aktivitetene, etter eierskap. $\mathrm{N}=141$. Aktiviteter der det er signifikant forskjell etter eierskap er markert med $\left.{ }^{\star}\right)(\mathrm{p}<.05)$.

\begin{tabular}{|c|c|}
\hline Rekrutteringsaktiviteter siste tre måneder: & Etter eierskap \\
\hline \multirow[t]{4}{*}{ ^) Informert om hverdag/rutiner i ordinær barnehage } & Kommune: $92,9 \%$ \\
\hline & Menighet: $61,0 \%$ \\
\hline & Andre eiere: $90,3 \%$ \\
\hline & Alle: $83,3 \%$ \\
\hline \multirow[t]{4}{*}{ Informert om ulike barnehager i kommunen } & Kommune: $87,1 \%$ \\
\hline & Menighet: $70,7 \%$ \\
\hline & Andre eiere: $74,2 \%$ \\
\hline & Alle: $80,1 \%$ \\
\hline \multirow[t]{4}{*}{ Gitt råd om hvilken barnehage en bør søke plass i } & Kommune: $50 \%$ \\
\hline & Menighet: $43,9 \%$ \\
\hline & Andre eiere: $71,0 \%$ \\
\hline & Alle: $53,5 \%$ \\
\hline \multirow[t]{4}{*}{ ^) Gitt hjelp til utfylling av barnehagesøknad } & Kommune: $60,0 \%$ \\
\hline & Menighet: $19,5 \%$ \\
\hline & Andre eiere: $32,3 \%$ \\
\hline & Alle: $41,7 \%$ \\
\hline \multirow[t]{4}{*}{ Framskaffet oversikt over ledige plasser i barnehager i kommunen } & Kommune: $32,9 \%$ \\
\hline & Menighet: $19,5 \%$ \\
\hline & Andre eiere: $25,8 \%$ \\
\hline & Alle: $27,8 \%$ \\
\hline \multirow[t]{4}{*}{ ^) Arrangert besøk til ordinær barnehage } & Kommune: $27,1 \%$ \\
\hline & Menighet: $7,3 \%$ \\
\hline & Andre eiere: $9,7 \%$ \\
\hline & Alle: $18,4 \%$ \\
\hline
\end{tabular}

Har spesielt oppfordret og hjulpet fremmedspråklige til å søke barnehageplass. Har fortalt mødrene om viktigheten av at de får gå $i$ barnehage (kommunal åpen barnehage).

Fordi dagen og aktivitetene $\mathrm{i}$ åpen barnehage har mange fellestrekk med ordinære barnehager, får foreldrene innblikk i og blir tryggere på barnehagen som institusjon. Da faller det naturlig å tenke seg at de som er nye i Norge trenger denne «innføringen» mest:

$V i$ er et viktig førstemøte med barnehage for mange, og gir et godt innblikk $i$ hvordan barnehage er. Vi kan derfor gi scerlig flerspråklige muligheten til å bli trygg på barnehage som organisasjon og dermed vere en døråpner til ordincer barnehage for disse barna (privat åpen barnehage).

Det er på den andre siden en del ledere, spesielt i menighetsbarnehagene, som reagerer negativt på at åpne barnehager skal ses på som en rekrutterings- eller tilvenningsarena for ordinære barnehager. Disse lederne er mer opptatt av den åpne barnehagens egenverdi og «egentlige intensjon»: 


\section{A. S. Haugset}

Har drevet barnehage siden 1993 og har aldri opplevd tilbudet som «oppvarming» til barnehagestart. Har aldri sett på det som dette, men som en barnehageform med egenverdi bygget på åpen barnehages egentlig intensjon (menighetsbarnehage).

Når både rekrutteringsaktiviteter og tro på at barnehagen rekrutterer til ordinær barnehage varierer systematisk etter eierskap, kan dette henge sammen med at ulike organisasjoner har ulike oppfatninger av hva som er åpen barnehages «egentlige intensjon». Med basis i ny-institusjonell organisasjonsteori, der mye vekt tillegges organisasjoner som kulturelt-kognitive strukturer (Scott, 2014, s. 55), kan en spørre om det finnes ulike implisitte, delte meningssystemer og oppfatninger i henholdsvis kommuner og menigheter når det gjelder hva en åpen barnehage er og skal være. Datamaterialet som er til rådighet er imidlertid ikke egnet til annet enn å reise spørsmålet, og svar må finnes i videre forskning.

Uavhengig av eierskap opplever ledere av åpne barnehager at en del familier giør bevisste, velfunderte valg om å utsette barnehagestarten - valg som lederne ønsker å støtte opp om og respektere og som åpen barnehage kan understøtte:

Apen barnehage egner seg til møteplass for familier som velger a vente med ordincer barnehage (gjerne store familier og minoritetsspråklige). Apen barnehage er et viktig tilskudd når man ikke velger et A4-barnehageliv (alle $i$ barnehage fra 1 år) (kommunal åpen barnehage).

Noen av kommentarene viser at barnehagelederen opplever at minoritetsspråklige familier og norske familier har valgt bort ordinær barnehage av ulike grunner, og at tilnærmingen til rekruttering blir ulik for disse gruppene. Mens ord som kvalitetstid og valgfrihet brukes for å beskrive de norskspråklige familienes valg, handler det om å «ufarliggiøre» og vise fram barnehagen for de minoritetsspråklige familiene.

Flere familier med utenlandsk opprinnelse blir oppmuntret og blir informert om det vanlige barnehagetilbudet $i$ kommunen. Vi ser at dette 'ufarliggjør' barnehagene, og de velger a oppsøke disse. Enkelte norske familier, som kjenner til de norske barnehagene, velger gjerne a vare hjemme litt lenge med barna sine $i$ den forste perioden - kvalitetstid! (menighetsbarnehage).

\section{Språklig bakgrunn som tommelfingerregel for rekruttering}

I innledningen av artikkelen viste jeg hvordan åpne barnehager befinner seg $\mathrm{i}$ et spenningsfelt av kryssende forventninger når det gjelder rekruttering til ordinær barnehage: Skal den åpne barnehagen supplere hjemmebarndommen med pedagogiske opplegg og sosiale møteplasser, og gjennom dette understøtte bevisste valgt gjort av myndige, reflekterte og kompetente foreldre, slik de skildres av Seeberg (2010) og Nadim (2012)? Eller skal målet være å gi usikre (minoritetsspråklige) brukerfamilier et så trygt og attraktivt inntrykk av barnehagen som institusjon at resultatet blir søknad om barnehageplass?

For lederne av åpne barnehager synes dette spørsmålet å handle vel så mye om hvem av brukerne som skal støttes i valget sitt, og hvem som skal påvirkes og «rekrutteres». Jo høyere andel minoritetsspråklige barn den åpne barnehagen har, jo høyere vurderer lederne at rekrutteringseffekten er. Andelen av brukere som ikke planlegger ordinær 
barnehage, altså hele den gruppen som kan rekrutteres uavhengig av språklig bakgrunn, henger imidlertid ikke sammen med rekrutteringseffekten i barnehagen. På grunn av den informantbaserte og dermed lite presise måten begge disse variablene er målt på, kan en ikke feste alt for stor lit til dette funnet alene. Men når det ses i lys av de åpne kommentarene som barnehagelederne gir, føyer det seg inn i et bilde der norsk/nordiskspråklige brukere og brukere med minoritetsspråk oppleves som svært ulike når det gjelder rekruttering. Det ser ut som minoritetsspråklig bakgrunn er en markør som barnehageleder og personale orienterer seg etter i rekrutteringsinnsatsen sin. Denne «tommelfingerregelen» kan begrunnes i tidligere forskning som viser at barn med minoritetsspråk har spesielt godt utbytte av å gå i barnehagen før skolestart (Drange \& Telle, 2011). Samtidig kan den være med på å opprettholde og forsterke stereotypier knyttet til etnisitet og språklig bakgrunn. Som både Nadim (2012) og Seeberg (2010) er inne på, så kan det å ha andre kulturelle røtter føre til andre preferanser når det gjelder barndom og barnetilsyn - noe også minoritetsspråklige familier har rett til å velge for sine barn. Det er heller ikke alle norske familier som velger bort barnehagen, som greier å kompensere for den fordelen barnet kunne hatt av å gå i barnehage (Havnes \& Mogstad, 2009, side 3).

Datamaterialet gir ikke svar på hvorfor ulikt eierskap gir ulikt fokus på rekruttering til ordinær barnehage. Det er naturlig å lete både i eierorganisasjonenes sentrale formål og oppgaver (Jørgensen, 1995) og i de kognitivt-kulturelle meningssystemene som preger de ulike institusjonene (Scott, 2014) - størrelser som sannsynligvis er tett forbundet med hverandre. Kommunen er velferdsstatens lokale representant, og derigjennom medansvarlig for blant annet sosial utjevning, integrering, like muligheter for alle og investering $\mathrm{i}$ framtidas arbeidskraft. Som organisasjon og institusjon har kommunen oppgaver og ansvar knyttet både til tjenester for enkeltindividet, for samfunnsgoder og for realisering av sentrale samfunnsverdier og normer (Jørgensen, 1995). Menighetsbarnehagene synes på sin side å ha en sterkere bevissthet rundt seg selv som et selvstendig pedagogisk alternativ til ordinær barnehage (Haugset \& Sivertsen, 2014). Som en del av en trosorganisasjon har menighetseide barnehager vanligvis også formål knyttet til formidling av verdier, tro og tradisjoner. Et liknende formidlingselement kan en også finne i åpne barnehager som er knyttet til andre ideelle organisasjoner (Haugset et al., 2014). Det er et spennende tema for videre undersøkelser hvorvidt og på hvilke måter forankringen i ulike organisasjoner påvirker oppfatningene leder og ansatte i åpne barnehager har av sitt virke og barnehagens oppgave og rolle.

\section{Oppsummering}

De som leder kommunale barnehager med 4-5 åpningsdager i uka og mange minoritetsspråklige brukere tror mest på rekrutteringseffekter i sin åpne barnehage. De kommunale åpne barnehagene har også mer aktivitet rettet mot rekruttering til ordinær barnehage enn barnehager med andre eiere. Kommentarer fra lederne i åpne barnehager viser at dilemmaet rundt rekruttering oppleves som «hvem av brukerne skal rekrutteres, og hvem skal støttes i valget sitt»? I dette spørsmålet 


\section{A. S. Haugset}

brukes minoritetsspråklig bakgrunn som et sentralt kriterium: Det kan synes som det i hovedsak er minoritetsspråklige familier som blir aktivt oppmuntret til å søke barnehageplass. Kommentarer fra barnehagelederne antyder dessuten at en del, spesielt i menighetseide barnehager, ikke føler seg komfortabel med at rekruttering til ordinær barnehage skal være den åpne barnehagens oppgave og rolle.

\section{Biografi}

Anne Sigrid Haugset (f. 1976) er sosiolog og har vært ansatt som forsker ved Trøndelag Forskning og Utvikling siden 2009. Hun arbeider i hovedsak med oppvekst- og utdanningsrelatert forskning og utredningsarbeid. Haugset har mastergrad i sosiologi fra NTNU (2011).

\section{Referanser}

Drange, N. \& Telle, K. (2011). Gratis kjernetid i barnehage: Effekt på skolekarakterene til barn fra innvandrerfamilier. I N.P. Sandbu (Red.): Utdanning 2011 - veien til arbeidslivet. Oslo: Statistisk sentralbyrå.

Ellingsæter, A. L. (2012). Familiepolitikk i klassesamfunnet. I A.L. Ellingsæter \& K. Widerberg (Red.): Velferdsstatens familier. Nye sosiologiske perspektiver (s. 100-121). Oslo: Gyldendal akademisk.

Ellingsæter, A. L. \& Gulbrandsen, L. (2003). Barnehagen: Fra selektivt til universelt velferdsgode. NOVA-rapport 24/03. Oslo: NOVA.

Ellingsæter, A. L. \& Widerberg, K. (Red.). (2012). Velferdsstatens familier. Nye sosiologiske perspektiver. (s. 1330). Oslo: Gyldendal akademisk.

Emhjellen, T. H. (2008). Helsefremmende arbeid $i$ ncermiljøet - med fokus på Åpen barnehages bidrag til å skape nettverk blant småbarnsmødre. (Masteroppgave) Helsefremmende arbeid, Høgskolen i Vestfold.

Erstad, I. (2012). Å oppdra barn er hardt arbeid. Foreldreskap i et lokalmiljø. I S. Alghasi, E. Eide og T. H. Eriksen: Den globale drabantbyen. Groruddalen og det nye Norge. Oslo: Cappelen Damm Akademisk.

Filipovic-Kittelsen, A. C. (2008). «Men alle er glad $i$ ungene sine, vil det beste for ungene sine, det er felles.». En kvalitativ undersøkelse av hva rådgivere $i$ to åpne barnehager vektlegger $i$ rådgiving med foreldre med flerkulturell bakgrunn. Masteroppgave i spesialpedagogikk, Universitetet i Oslo.

Hatlem, M. (2008). Åpen barnehage - en møteplass $i$ et fellesskapsperspektiv. Masteroppgave i barnehage- og profesjonsutvikling ved Danmarks Pædagogiske Universitetshøgskole. København: Århus universitet.

Hatlem, M. \& Frank, C. (2009). Den åpne barnehagen - et tilbud med egenverdi og en port inn til den ordinære barnehagen. Første steg, mai-juni, 2009, 30-31.

Haugset, A. S., Gotvassli, K-Å., Ljunggren, B. \& Stene, M. (2014). Apne barnehager $i$ Norge. Organisering, bruk og betydning. Rapport 2014:5. Steinkjer: Trøndelag Forskning og Utvikling AS.

Haugset, A. S. \& Sivertsen, H. (2014). Ånne barnehager $i$ Norge. En kartlegging av omfang og organisering. Arbeidsnotat 2014:5. Steinkjer: Trøndelag Forskning og Utvikling AS.

Havnes, T. \& Mogstad, M. (2009). No Child Left Behind. Universal Child Care and Children's Long-Run outcomes. Discussiom Paper No. 582. Oslo: Statistisk sentralbyrå.

Håkonsen, L., Løyland, K. \& Aastvedt, A. (2014). Finansiering av ikke-kommunale barnehager. Pensjonskostnad, kapitalkostnad, ånne barnehager. TF-rapport nr. 333. Bø i Telemark: Telemarksforskning.

Jacobsen, T. G. (2013). The Logic behind Statistical Inference - Sample Theory, Population Size, and Stochastic Model Theory. I Popular Social Science - Bridging the gap. Hentet fra http://www. popularsocialscience.com/2013/04/03/the-logic-behind-statistical-inference-sample-theory-population-sizeand-stochastic-model-theory/

Jørgensen, T. B. (1995). Offentlige organisasjoners oppgaver. Politica, desember 1995.

Leira, A. (2012). Omsorgens institusjoner, omsorgens kjønn. I A. L. Ellingsæter \& K. Widerberg (Red.). Velferdsstatens familier. Nye sosiologiske perspektiver (s. 76-98). Oslo: Gyldendal akademisk.

Mellin-Olsen, A. E. (2014). Håpet fødes i handling. Erfaringer fra arbeid i en flerspråklig åpen barnehage. I N. Lindèn og L. M. Moberg (Red.): Leik og skapende aktiviteter. Språkstimulering $i$ barnehagen. Oslo: Gyldendal akademiske forlag.

Mogstad, M. \& Rege, M. (2009). Tidlig læring og sosial mobilitet: Norske barns muligheter til å lykkes i utdanningsløpet og arbeidslivet. Samfunnsøkonomen nr. 5-09. 


\section{Apne barnehager som rekrutteringsarena}

Mortensen, Ø. \& Fosse, E. (2006). «Empowerment i praksis». Evaluering av Kirkens bymisjons narmiljøarbeid Ada. Rapport fra HEMIL-senteret. Bergen: Universitetet i Bergen.

Nadim, M. (2012). Mellom familie og arbeid. Moralske forhandlinger blant kvinnelige etterkommere. I A.L. Ellingsæter \& K. Widerberg (Red.). Velferdsstatens familier. Nye sosiologiske perspektiver (s. 289-308). Oslo: Gyldendal akademisk.

Regjeringen. (2012). Mld. St. 24 2012-2013. Framtidens barnehage. Oslo: Kunnskapsdepartementet.

Ringdal, K. (2007). Enhet og mangfold. Samfunnsvitenskapelig forskning og kvantitativ metode. Bergen: Fagbokforlaget.

Scott, W. R. (2014). Institutions and Organizations. Ideas, Interest, and Identities (Fourth Edition). Thousand Oaks: Sage Publications.

Seeberg, M. L. (2010). Siste skanse: En undersøkelse om 3-5-åringer som ikke går i barnehage. Rapport 7/10. Oslo: NOVA - Norsk institutt for forskning om oppvekst, velferd og aldring.

Skolverket. (2005). Öppen förskolas utveckling. En studie av perioden 1980-2005. Rapport 269-2005. Stockholm: Skolverket.

Tingstad, V. \& Kvamstad, V. (1998). Apen barnehage. Kvinnecafe eller møteplass med barnet $i$ sentrum? Rapport nr. 51. Trondheim: Norsk senter for barneforskning.

Thoresen, I. T. (2009). Barnehagen i et utdanningspolitisk kraftfelt. Nordisk barnehageforskning 2, 2009(3), 127-137.

Thyrhaug, A. M. (2009). Familiens hus. Nasjonal kartleggingsundersøkelse 2008. RBUP Nord rapport 3:2009. Tromsø: Universitetet i Tromsø, det medisinske fakultet.

Utdanningsdirektoratet (2015). Barnehagespeilet 2015. Tall og analyse av barnehager $i$ Norge. Oslo: Utdanningsdirektoratet. 